Hydrol. Earth Syst. Sci. Discuss.,

https://doi.org/10.5194/hess-2018-603-AC1, 2019

(C) Author(s) 2019. This work is distributed under

the Creative Commons Attribution 4.0 License.

\title{
Interactive comment on "Evaluation of drought representation and propagation in Regional Climate Model simulations over Spain" by Anaïs Barella-Ortiz and Pere Quintana-Seguí
}

Anaïs Barella-Ortiz and Pere Quintana-Seguí

abarella@obsebre.es

Received and published: 12 March 2019

Dear Referee, The reply to your comments is given in the pdf document provided as a supplement. Yours sincerely, Anaïs Barella-Ortiz

Please also note the supplement to this comment:

https://www.hydrol-earth-syst-sci-discuss.net/hess-2018-603/hess-2018-603-AC1-

Printer-friendly version supplement.pdf

Interactive comment on Hydrol. Earth Syst. Sci. Discuss., https://doi.org/10.5194/hess-2018- 